\title{
The role of toll-like receptors in colorectal cancer progression: evidence for epithelial to leucocytic transition
}

\author{
Kimberly A. Luddy ${ }^{1}$, Mark Robertson-Tessi ${ }^{2}$, Narges K. Tafreshi ${ }^{1}$, Hatem Soliman ${ }^{3}$ and David L. Morse ${ }^{1}$ * \\ ${ }^{1}$ Department of Cancer Imaging and Metabolism, Imaging and Technology Center of Excellence, H. Lee Moffitt Cancer Center, Tampa, FL, USA \\ 2 Department of Integrated Mathematical Oncology, H. Lee Moffitt Cancer Center, Tampa, FL, USA \\ ${ }^{3}$ Don and Erika Wallace Comprehensive Breast Program, Center for Women's Oncology, H. Lee Moffitt Cancer Center and Research Institute, Tampa, FL, USA
}

Edited by:

Anton G. Kutikhin, Russian Academy

of Medical Sciences, Russia

\section{Reviewed by:}

Alessio Paone, Sapienza University of Rome, Italy

Anton G. Kutikhin, Russian Academy

of Medical Sciences, Russia

*Correspondence:

David L. Morse, Department of Cancer Imaging and Metabolism Imaging and Technology Center of Excellence, $H$. Lee Moffitt Cancer Center, Tampa, FL, USA

e-mail: David.Morse@moffitt.org
Toll-like receptors (TLRs) are expressed by immune cells, intestinal epithelium, and tumor cells. In the homeostatic setting, they help to regulate control over invading pathogens and maintain the epithelial lining of the large and small intestines. Aberrant expression of certain TLRs by tumor cells can induce growth inhibition while others contribute to tumorigenesis and progression. Activation of these TLRs can induce inflammation, tumor cell proliferation, immune evasion, local invasion, and distant metastasis. These TLR-influenced behaviors have similarities with properties observed in leukocytes, suggesting that tumors may be hijacking immune programs to become more aggressive. The concept of epithelial to leucocytic-transition (ELT) is proposed, akin to epithelial to mesenchymal transition, in which tumors develop the ability to activate leucocytic traits otherwise inaccessible to epithelial cells. Understanding the mechanisms of ELT could lead to novel therapeutic strategies for inhibiting tumor metastasis.

Keywords: colorectal cancer, toll-like receptors, epithelial to leucocytic transition, ELT, metastasis, immune evasion, cell plasticity, inflammation

\section{INTRODUCTION}

Toll-like receptors (TLRs) are a diverse family of pattern recognition receptors expressed by immune cells from both the innate and adaptive arms of the immune system (1-4). Hence, TLRs stimulate both innate and adaptive immune responses to invading pathogen-associated molecular patterns (PAMPs) as well as danger-associated molecular patterns (DAMPs) from damaged epithelial cells. Ligand specificity, downstream signaling, and subsequent immune stimulation vary greatly among the TLR subtypes $(5,6)$. The complex expression patterns of TLRs differ among cell types, physiological location, and are controlled by the microenvironment (7-9). In the healthy gastrointestinal (GI) tract, TLRs are expressed by intestinal epithelial cells (IEC) and play a role in immune modulation and tissue homeostasis by stimulating the immune response to bacterial pathogens, attenuating the immune response against favorable microbes, sensing breakdown of the protective intestinal barriers, and triggering proliferative signaling $(6,10,11)$. The lumen of the gut is subjected to continual interactions with the microbiome and would be in a constant state of inflammation were it not for the controlled expression and normal function of these TLRs $(2,6)$.

Inflammation has been implicated as an underlying factor in tumorigenesis and cancer progression, leading transformed cells to develop the "hallmarks of cancer" $(12,13)$. Some of the same TLRs (TLR 2-4) that normally regulate inflammation in the gut are also found to be aberrantly expressed in colorectal cancers (CRCs) $(14,15)$. Overexpression of TLR4 in CRC is associated with poor survival (16). Deletion of TLR4, its signaling partner Myd88, or absence of its ligand LPS in the colon can lead to increased or reduced inflammation, depending on the cancer subtype, which can then lead to either increased or decreased tumorigenesis and tumor progression $(17,18)$. It is notable that the role of TLRs in CRC reflects a "natural history" of selection events that lead from normal TLR function in unaffected colon tissue and throughout all stages of CRC progression. More specifically, the normal role of TLR immune modulation in the gut involves the controlled release of cytokines and danger signals that stimulate the immune response to bacterial pathogens and attenuate the immune response against favorable microbes $(6,10)$. Microbial imbalance and/or dysregulation of these responses leads to chronic inflammation of the bowel (15). Chronic inflammation is correlated with initiation of cancer development and in the progression of cancer into more aggressive forms of malignancies (2). Aberrant TLR signaling and the resulting cytokine imbalance leads to increased epithelial proliferation and decreased cell death (19). Additionally, an active immune environment creates selection pressures for initiating cancer cells resulting in the evolution of an immuneevasive tumor phenotype (14). Furthermore, TLR dysregulation is implicated in cancer invasion and metastasis $(2,19-21)$. Understanding the role of TLRs in the natural evolution of metastatic disease is crucial for developing new therapies and optimizing current treatments.

\section{ROLE OF TLRS IN INFLAMMATION-MEDIATED TUMORIGENESIS}

The intestines house approximately $70 \%$ of the body's immune cells under normal conditions (10). Signaling between these 
immune cells, commensal bacteria, and IECs is critical for normal digestion and protection against invading pathogens (6). TLRs are key modulators of the immune system of the GI tract. In order to maintain homeostasis and suppress immune responses to commensal bacteria (11), TLR expression and signaling are tightly controlled in this environment $(6,20)$. However, these controls are disrupted in diseases such as Crohn's disease and ulcerative colitis, resulting in chronic inflammation $(11,15)$. Inflammation is linked to cancer through two pathways: extrinsic inflammation induced by non-transformed cells (e.g., invading pathogens or autoimmune disease), and intrinsic inflammation induced by transformed cells (22). In CRC, TLRs are involved in both. Autoimmune diseases cause chronic, smoldering levels of inflammation that predispose individuals into developing CRC (22). Once initiated, tumors can intrinsically activate inflammation through TLR binding by cancer-related DAMPs. Intrinsically and extrinsically induced TLR activation results in tumor-promoting inflammation through NF- $\mathrm{B}$ signaling, leading to expression of the inflammatory cytokines IL-1 $\beta, \mathrm{TNF} \alpha$, and IL-6 (17). This aberrant expression by tumor cells in early carcinogenesis can recruit tumor-promoting immune cells, leading to inflammation and protection from cytotoxic immune cells. Additional data from Kim et al. links mutations in p53 and PTEN to SOCS-mediated activation of IL- 6 signaling, leading to intrinsic inflammation (23). Since p53 mutation is a very common event in the natural history of CRC, this is likely a major mechanism of tumor-induced inflammation. Additionally, inflammation can drive genetic and epigenetic changes in cells as well as possible alterations in lineage differentiation programs leading to increased plasticity. This process is also thought to involve NF- $\mathrm{BB}$ signaling; however, further studies are needed $(22,24)$.

\section{ROLE OF TLRS IN INFLAMMATION-MEDIATED PROLIFERATION AND SURVIVAL}

Inflammatory pathways are tightly linked to aberrant proliferation and resistance to cell death, which are key cancer hallmarks that can be mediated through TLR activation (14). IECs are the barrier layer that protects the interstitial layers from the changing exterior environment of the GI tract. Infiltrating bacteria and the resulting immune response can cause tissue damage. To prepare for this, IECs utilize TLR4 signaling as an early warning system to initiate proliferation, maintain tissue integrity, and protect the interstitial compartments (6). Tumors can co-opt this system, allowing cells to proliferate unchecked (25).

Tumor growth is further fueled through an overabundance of growth factors (e.g., TGF- $\beta$, IL-8, CXCR4, and VEGF) (15), a decline in immune surveillance, and the evolution of mobile and invasive phenotypes. TLR expression on tumor cells stimulates the release of cytokines that recruit favorable immune cells further driving proliferation. Additionally, the release of cytokines and chemokines due to TLR signaling generates an autocrine loop that further stimulates tumor cell growth. The cumulative result is tumor control over its own environment.

\section{ROLE OF TLRS IN IMMUNE EVASION}

An active immune environment selects for the natural evolution of cancer cells with decreased immunogenic phenotypes. TLR expression in tumors can confer the advantages of both immune evasion and immunosuppression (26). Often pro-inflammatory signals reduce elements of the adaptive immune response. TLR signaling causes a shift in this response from anti-tumor to pro-tumor by affecting the balance toward inflammation and suppression of anti-tumor immunity. Direct TLR activation results in production of immunosuppressive cytokines IL-10 and TGF- $\beta(14,27)$, as well as increased expression of immune modulating surface markers PD-L1 and HLA-G $(19,20,28)$. These secreted and surface proteins have a tolerizing effect on immune cells. TLR-activated IECs induce the transformation of dendritic cells (DC) into an antigen-specific CD103+ phenotype. These DC promote contactdependent antigen-specific regulatory $\mathrm{T}$ cells (Tregs) that express gut-homing integrins, which further attenuates the anti-tumor immune response (10). Each of these mechanisms are used in the healthy gut to avoid food hypersensitivity or auto-immune diseases. However, dysregulation through abnormal TLR expression can lead to malignant progression.

\section{ROLE OF TLRS IN INVASION AND METASTASIS}

The most dangerous effect of tumoral TLR signaling is the acquisition of invasive and metastatic tumor phenotypes (29). Ninety percent of patients who succumb to their disease have metastatic lesions (30). TLR expression in tumors is linked to increased grade and distant metastasis $(2,18,21,31)$. The ability of a tumor cell to detach from its epithelial neighbors, break through the basement membrane, and invade nearby tissues is, in part, the result of a long history of aberrant TLR signaling. In CRC, TLR-mediated alterations of the immune system components in the tumor microenvironment can change intracellular signaling (NF-кB), integrin expression (B1 integrin), and motility $(29,32)$. Activation of TLR4 by LPS in vitro and in vivo induces epithelial to mesenchymal transition (EMT) and invasive phenotypes in certain cell lines $(29,33)$.

Immune cells are educated by tumor-secreted factors and then actively migrate through the lymphatic vessels and secondary lymphoid organs. These tightly gated organs allow entry and passage to soluble antigens and select immune cell phenotypes, and yet lymph nodes are often the first site of metastasis (34). While it was once thought that tumors cells passively filter into draining lymph nodes, it has recently been shown that tumor cells require chemokine-mediated (CCR7 and CCR8) active transport through the subcapsular sinus epithelium $(35,36)$. Furthermore, it has been shown that tumor-mediated lymphatic remodeling of peritumoral lymph vessels and draining lymph nodes facilitates metastasis (3740). TLRs may play a role in this metastatic process, since TLR activation leads to increased expression of CCR7 and CCR8 (41), which are key molecules expressed by leukocytes to access lymphatics $(35,42)$. This suggests that the tumor cells can harness existing leucocytic mechanisms to begin the metastatic cascade through the lymph nodes.

Lymphocytes typically traffic throughout the body to sites of inflammation, using chemokines, selectins, and integrins as 
homing signals (43). Many metastatic tumors have been shown to use the expression of these same molecules to colonize distal sites $(44,45)$. As an example, CXCR4 is a well-characterized bone marrow homing receptor expressed by T cells (46); research has found that both prostate cancers (47) and breast cancers (48) that metastasize to the bone commonly express CXCR4. CRC typically metastasizes to the liver or lung. Aberrant expression of CXCR3, CXCR4/CXCR7, and CCR6 are commonly found in liver and lung metastasis of colon cancer (49-55). Ligands for these receptors (CXCL19, SDF-1, and CCL20, respectively) are highly expressed in the liver and lungs of metastatic CRC patients $(53,56-58)$. Local inflammation in these organs induces ligand expression and preferential organ metastasis is determined by their expression $(59,60)$.

Alteration in integrin signaling is another metastatic mechanism induced by TLR signaling (26). Integrin signaling is used in healthy systems to aid immune cell trafficking (61). Aberrant expression of these integrins via TLR signaling allows circulating tumor cells to respond to the same trafficking mechanisms that an immune cell uses to migrate to distal sites $(2,32,62,63)$. Similar examples have been shown with integrins in colon cancer (64), breast cancer (65), and melanoma (66). These expressed surface markers are a natural part of the lymphocytic trafficking system, and their expression on tumor cells could be evidence that tumor cells use leucocytic trafficking mechanisms to metastasize.

\section{EPITHELIAL TO LEUCOCYTIC TRANSITION}

The co-opting of immune cell signaling and migration mechanisms by tumor cells is well documented, with many citing the plasticity of tumor cells and inappropriate gene expression as the underlying cause of treatment resistance and metastatic growth (13, 67-70). Pressures from cytotoxic immune cells, abundant inflammation, cytotoxic drugs, and targeted therapies push tumor cells into plastic states where they may begin to access programed mechanisms outside of their usual function (68). The survivors of these selection pressures are adaptive and dynamic cells, many of which express patterns of proteins found in other normal cell types $(70,71)$. These protein expression patterns have been used to define and detect EMT, for example. An increasing number of publications suggest that although EMT is important in locally invasive disease, it is not enough to allow tumor cells access to lymph nodes, lymphatic and vascular systems, as well as entrance and settlement into distant tissues $(35,69,72,73)$. Others hypothesize a myeloid lineage expression pattern gained from horizontal gene transfer and Lamarckian inheritance, tumor cell myeloid cell fusion, or a possible myeloid cell origin $(69,74-76)$. Here, we build on these observations and propose a new concept, the transition from epithelial phenotype to leucocytic phenotype.

Immune cells of myeloid and lymphoid origins house a diverse set of mechanisms that make them perfect trafficking cells. They can shift their metabolism easily, survive in low oxygenated areas, roll along the endothelium in the presence of high shear forces, read integrin codes, and facilitate tissue specific extravasation (7779). As described above, the aberrant expression of TLRs by CRC cells results in the acquisition of a number of tumor-promoting mechanisms. At the same time, these mechanisms are key properties of the immune system, as is TLR expression. In a broad sense, immunosuppression, migration through tissue, intra- and extravasation through lymph and blood vessels, rapid proliferation, altered metabolism, and homing to specific tissues are key hallmarks of both cancer and the immune system.

Pathogenic EMT has its roots in normal embryogenesis. In cancer, this transition results in epithelial cells with a range of mesenchymal protein expression. These alterations increase motility and invasive capability of tumor cells, but do not necessarily explain immunoevasion, lymphatic access, and metastatic spread $(35,69,72)$. We therefore propose the parallel concept of epithelial to leucocytic transition (ELT) as a framework, akin to EMT, with which to understand the metastatic properties of cancer cells. Figure 1 illustrates the primary properties gained by tumor cells that undergo ELT. We consider ELT to be a partial transition in which epithelial cells retain their epithelial origin while at the same time acquiring a set of leucocytic traits. Tumor cells co-opt many mechanisms of the immune system for their own transport and these mechanisms are activated by proteins typically reserved for

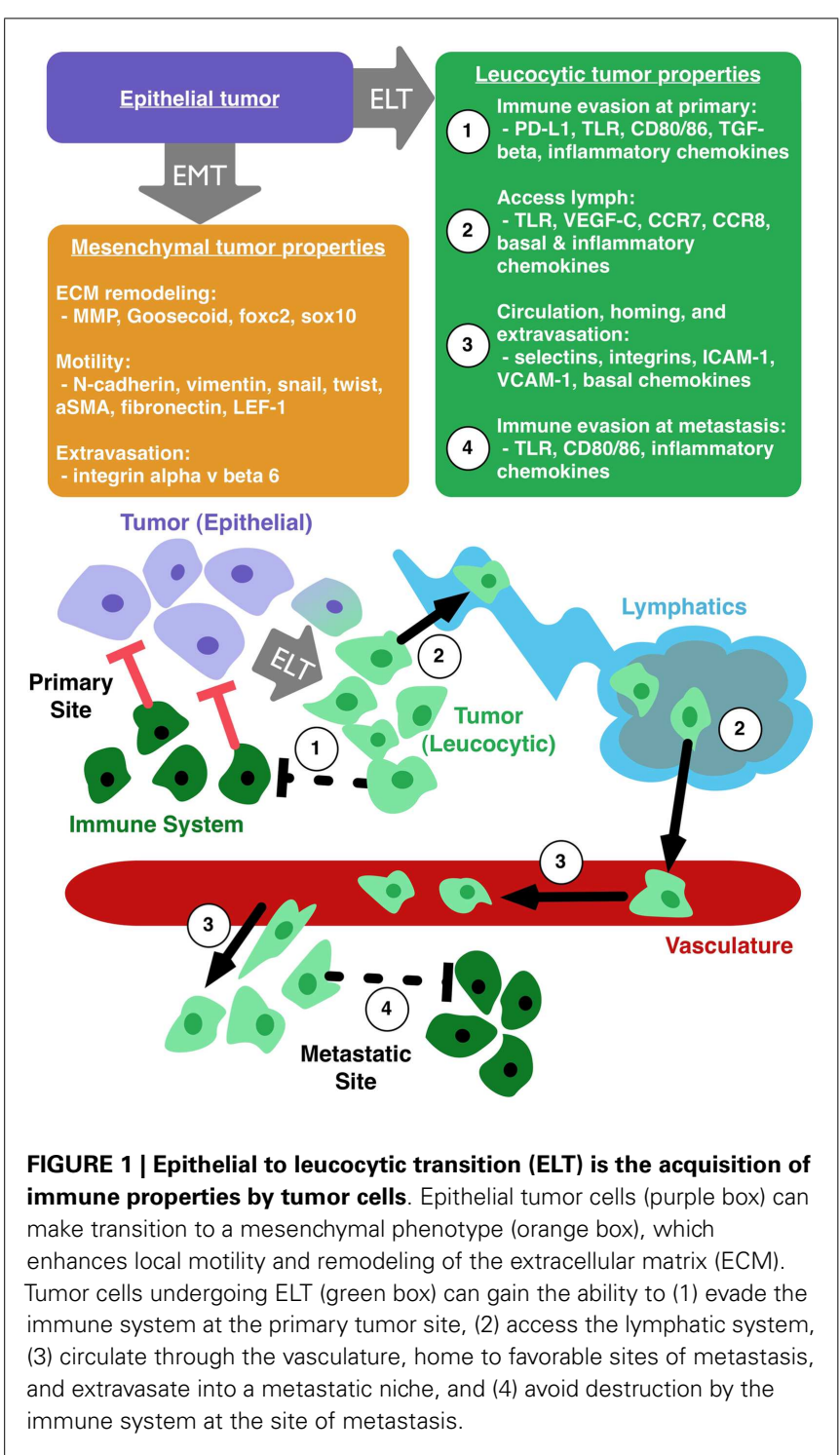


the immune response. A leucocytic tumor cell expresses proteins that allow for regulation and co-opting of the immune system such as PD-L1, CD80/86, TLR, TGF- $\beta$, CCL4, and CCL5 (80) (Figure 1, properties 1 and 4). Additional leucocytic proteins (CXCR4, CCR7, CCR8) facilitate invasion and proliferation within lymph nodes (Figure 1, property 2) $(35,42,81)$. Processes critical to survival in circulation, homing to tissue specific sites, and successful extravasation are mediated by E/P-selectins, L-selectin ligands, $\alpha 4 \beta 1$, ICAM-1, and VCAM-1 (61, 73, 82-86) (Figure 1, property 3). By harnessing mechanisms usually reserved for immune cells, tumor cells gain the ability to become more aggressive. In the case of TLRs, a cycle of overexpression and resulting inflammation promotes plasticity of the epithelial phenotype. This plasticity permits tumor cells to undergo ELT, accessing immune programs that facilitate invasion and metastasis of the cancer. ELT, as with other plastic states, is likely transient, making the evaluation of these phenotypes a significant challenge. TLR-mediated evolution of CRC may be a good model to study how ELT occurs, since TLRs are primarily seen in immune cells and the overexpression of TLRs appears to promote an immune-like phenotype in CRC.

Understanding the acquisition of the leucocytic phenotype could reveal key targets that would prevent CRC cells from accessing dangerous invasion and trafficking mechanisms through a plastic transition. Simply antagonizing TLRs and associated molecules may not be enough, since resistance is likely to develop. However, if the mechanisms of plasticity induced by TLRs are understood, new targets may be developed to inhibit ELT.

It is important to note that the key functional activities of immune cells, specifically the CD8 cytotoxic T-cell phenotype and the antibody producing activated B-cell phenotypes, have not yet been described in tumor cells. However, other cytotoxic mechanisms utilized by immune cells have been seen in normal and neoplastic epithelial cells. Tumor cell cannibalism, resembling phagocytosis, of neighboring apoptotic cells as well as infiltrating immune cells has been seen during times of metabolic stress (87). During mammary involution, epithelial-derived FAS plays a role in FASL-mediated cell death (88). Tumor cells can secrete FAS, TNFa, and TGFb, proteins capable of promoting and inhibiting epithelial cell death (89-91). Additionally, PD-L1 proteins on tumor cells result in T-cell anergy and apoptosis (92,93). Although, none of these represent the antigen-specific killing of the adaptive immune system, it is our opinion that further exploration is needed to determine how far epithelial cells can evolve to obtain immune-like processes and that cell killing can not yet be included or excluded from that hypothesis.

\section{CONCLUSION}

Originally, lymphatic dissemination into draining lymph nodes was considered a clear indicator of prognosis and was attributed to tumor chronology based on the correlation of tumor volumes and lymph node metastasis. However, later larger studies often showed conflicting results. Jatoi et al. $(94,95)$ and others attributed these differences to the tumor phenotype as opposed to a simple passage of time. This means that tumor phenotypes can exist on a continuum from slow growing with late lymph node metastasis to aggressive early disseminators much more capable of exiting the lymph node and establishment at distant sites (94, 95).
While lymph node positivity is a useful tool for treatment decisions understanding the complexities of these aggressive phenotypes is key to halting the lymphatic dissemination of cancer.

Many host parameters contribute to natural progression of tumor metastasis and the extent of tumor cell plasticity is not yet fully appreciated. In an opinion article on tumor and immune cell plasticity, Holzel et al. (68) recognize the similarity between cancer cells and immune cells by linking inflammation and evolutionary pressures to the creation of plastic phenotypes. We think that this idea needs to be taken further to include a plastic transition to an immune-like phenotype, i.e., ELT, in the context tumor development, invasion, metastasis, and resistance to therapies. Specifically in CRC, the tumor cells acquire many hallmarks of the immune system, and this transition is intimately tied to aberrant TLR expression. By considering TLR expression in the context of ELT, the transition to a migratory immune-like and therefore metastatic phenotype might be better understood, and therefore, lead to better therapeutic strategies.

\section{REFERENCES}

1. Rahman AH, Taylor DK, Turka LA. The contribution of direct TLR signaling to T cell responses. Immunol Res (2009) 45(1):25-36. doi:10.1007/s12026-0098113-x

2. Lu Q, Ding H, Li W. Role of toll-like receptors in microbiota-associated gastrointestinal cancer metastasis. J Cancer Res Ther (2013) 9(Suppl):S142-9. doi:10.4103/0973-1482.122509

3. Du T, Zhou ZG, You S, Huang G, Lin J, Yang L, et al. Modulation of monocyte hyperresponsiveness to TLR ligands by 1,25-dihydroxy-vitamin D3 from LADA and T2DM. Diabetes Res Clin Pract (2009) 83(2):208-14. doi:10.1016/j.diabres. 2008.09.046

4. Hua Z, Hou B. TLR signaling in B-cell development and activation. Cell Mol Immunol (2013) 10(2):103-6. doi:10.1038/cmi.2012.61

5. Akira S, Takeda K. Toll-like receptor signalling. Nat Rev Immunol (2004) 4(7):499-511. doi:10.1038/nri1391

6. Abreu MT. Toll-like receptor signalling in the intestinal epithelium: how bacterial recognition shapes intestinal function. Nat Rev Immunol (2010) 10(2):131-44. doi:10.1038/nri2707

7. Zarember KA, Godowski PJ. Tissue expression of human toll-like receptors and differential regulation of toll-like receptor mRNAs in leukocytes in response to microbes, their products, and cytokines. J Immunol (2002) 168(2):554-61. doi:10.4049/jimmunol.168.2.554

8. Applequist SE, Wallin RP, Ljunggren HG. Variable expression of toll-like receptor in murine innate and adaptive immune cell lines. Int Immunol (2002) 14(9):1065-74. doi:10.1093/intimm/dxf069

9. Takenaka S, McCormick S, Safroneeva E, Xing Z, Gauldie J. Influence of the tissue microenvironment on toll-like receptor expression by CD11c+ antigenpresenting cells isolated from mucosal tissues. Clin Vaccine Immunol (2009) 16(11):1615-23. doi:10.1128/CVI.00216-09

10. de Kivit S, Tobin MC, Forsyth CB, Keshavarzian A, Landay AL. Regulation of intestinal immune responses through TLR activation: implications for pro- and prebiotics. Front Immunol (2014) 5:60. doi:10.3389/fimmu.2014.00060

11. Cario E. Toll-like receptors in inflammatory bowel diseases: a decade later. Inflamm Bowel Dis (2010) 16(9):1583-97. doi:10.1002/ibd.21282

12. Hanahan D, Weinberg RA. Hallmarks of cancer: the next generation. Cell (2011) 144(5):646-74. doi:10.1016/j.cell.2011.02.013

13. Coussens LM, Werb Z. Inflammation and cancer. Nature (2002) 420(6917):860-7. doi:10.1038/nature01322

14. Ridnour LA, Cheng RY, Switzer CH, Heinecke JL, Ambs S, Glynn S, et al. Molecular pathways: toll-like receptors in the tumor microenvironment - poor prognosis or new therapeutic opportunity. Clin Cancer Res (2013) 19(6):1340-6. doi:10.1158/1078-0432.CCR-12-0408

15. Sato Y, Goto Y, Narita N, Hoon DS. Cancer cells expressing toll-like receptors and the tumor microenvironment. Cancer Microenviron (2009) 2(Suppl 1):205-14. doi:10.1007/s12307-009-0022-y 
16. Eiro N, Gonzalez L, Gonzalez LO, Fernandez-Garcia B, Andicoechea A, Barbon E, et al. Toll-like receptor-4 expression by stromal fibroblasts is associated with poor prognosis in colorectal cancer. J Immunother (2013) 36(6):342-9. doi:10.1097/CJI.0b013e31829d85e6

17. Pradere JP, Dapito DH, Schwabe RF. The Yin and Yang of toll-like receptors in cancer. Oncogene (2013) 33(27):3485-95. doi:10.1038/onc.2013.302

18. Salcedo R, Worschech A, Cardone M, Jones Y, Gyulai Z, Dai RM, et al. MyD88mediated signaling prevents development of adenocarcinomas of the colon: role of interleukin 18. J Exp Med (2010) 207(8):1625-36. doi:10.1084/jem.20100199

19. Yu L, Wang L, Chen S. Dual character of toll-like receptor signaling: protumorigenic effects and anti-tumor functions. Biochim Biophys Acta (2013) 1835(2):144-54. doi:10.1016/j.bbcan.2012.10.006

20. Huang B, Zhao J, Unkeless JC, Feng ZH, Xiong H. TLR signaling by tumor and immune cells: a double-edged sword. Oncogene (2008) 27(2):218-24. doi:10.1038/sj.onc.1210904

21. O'Leary DP, Bhatt L, Woolley JF, Gough DR, Wang JH, Cotter TG, et al. TLR-4 signalling accelerates colon cancer cell adhesion via NF-kappaB mediated transcriptional up-regulation of Nox-1. PLoS One (2012) 7(10):e44176. doi:10.1371/journal.pone.0044176

22. Mantovani A, Allavena P, Sica A, Balkwill F. Cancer-related inflammation. Nature (2008) 454(7203):436-44. doi:10.1038/nature07205

23. Kim G, Ouzounova M, Quraishi AA, Davis A, Tawakkol N, Clouthier SG, et al. SOCS3-mediated regulation of inflammatory cytokines in PTEN and p53 inactivated triple negative breast cancer model. Oncogene (2014). doi:10.1038/onc. 2014.4

24. Kwon OJ, Zhang L, Ittmann MM, Xin L. Prostatic inflammation enhances basal-to-luminal differentiation and accelerates initiation of prostate cancer with a basal cell origin. Proc Natl Acad Sci U S A (2014) 111(5):E592-600. doi:10.1073/pnas.1318157111

25. Yang H, Zhou H, Feng P, Zhou X, Wen H, Xie X, et al. Reduced expression of toll-like receptor 4 inhibits human breast cancer cells proliferation and inflammatory cytokines secretion. J Exp Clin Cancer Res (2010) 29:92. doi:10.1186/1756-9966-29-92

26. Montero Vega MT, de Andres Martin A. The significance of toll-like receptors in human diseases. Allergol Immunopathol (Madr) (2009) 37(5):252-63. doi:10.1016/j.aller.2009.04.004

27. Lu H. TLR agonists for cancer immunotherapy: tipping the balance between the immune stimulatory and inhibitory effects. Front Immunol (2014) 5:83. doi:10.3389/fimmu.2014.00083

28. Huang B, Zhao J, Li H, He KL, Chen Y, Chen SH, et al. Toll-like receptors on tumor cells facilitate evasion of immune surveillance. Cancer Res (2005) 65(12):5009-14. doi:10.1158/0008-5472.CAN-05-0784

29. Killeen SD, Wang JH, Andrews EJ, Redmond HP. Bacterial endotoxin enhances colorectal cancer cell adhesion and invasion through TLR-4 and NF-kappaBdependent activation of the urokinase plasminogen activator system. Br J Cancer (2009) 100(10):1589-602. doi:10.1038/sj.bjc.6604942

30. Weigelt B, Peterse JL, van't Veer LJ. Breast cancer metastasis: markers and models. Nat Rev Cancer (2005) 5(8):591-602. doi:10.1038/nrc1670

31. Gonzalez-Reyes S, Marin L, Gonzalez L, Gonzalez LO, del Casar JM, Lamelas ML, et al. Study of TLR3, TLR4 and TLR9 in breast carcinomas and their association with metastasis. BMC Cancer (2010) 10:665. doi:10.1186/1471-2407-10-665

32. Wang JH, Manning BJ, Wu QD, Blankson S, Bouchier-Hayes D, Redmond HP. Endotoxin/lipopolysaccharide activates NF-kappa B and enhances tumor cell adhesion and invasion through a beta 1 integrin-dependent mechanism. $J$ Immunol (2003) 170(2):795-804. doi:10.4049/jimmunol.170.2.795

33. Jing YY, Han ZP, Sun K, Zhang SS, Hou J, Liu Y, et al. Toll-like receptor 4 signaling promotes epithelial-mesenchymal transition in human hepatocellular carcinoma induced by lipopolysaccharide. BMC Med (2012) 10:98. doi:10.1186/1741-7015-10-98

34. Alitalo K. The lymphatic vasculature in disease. Nat Med (2011) 17(11):1371-80. doi: $10.1038 / \mathrm{nm} .2545$

35. Das S, Sarrou E, Podgrabinska S, Cassella M, Mungamuri SK, Feirt N, et al. Tumor cell entry into the lymph node is controlled by CCL1 chemokine expressed by lymph node lymphatic sinuses. J Exp Med (2013) 210(8):1509-28. doi:10.1084/jem.20111627

36. Ben-Baruch A. Organ selectivity in metastasis: regulation by chemokines and their receptors. Clin Exp Metastasis (2008) 25(4):345-56. doi:10.1007/s10585007-9097-3
37. Fukumura D, Duda DG, Munn LL, Jain RK. Tumor microvasculature and microenvironment: novel insights through intravital imaging in pre-clinical models. Microcirculation (2010) 17(3):206-25. doi:10.1111/j.1549-8719.2010. 00029.x

38. Ji RC. Lymph node lymphangiogenesis: a new concept for modulating tumor metastasis and inflammatory process. Histol Histopathol (2009) 24(3):377-84.

39. Achen MG, Stacker SA. Molecular control of lymphatic metastasis. Ann N Y Acad Sci (2008) 1131:225-34. doi:10.1196/annals.1413.020

40. He Y, Kozaki K, Karpanen T, Koshikawa K, Yla-Herttuala S, Takahashi T, et al. Suppression of tumor lymphangiogenesis and lymph node metastasis by blocking vascular endothelial growth factor receptor 3 signaling. J Natl Cancer Inst (2002) 94(11):819-25. doi:10.1093/jnci/94.11.819

41. Monteleone I, Platt AM, Jaensson E, Agace WW, Mowat AM. IL-10-dependent partial refractoriness to toll-like receptor stimulation modulates gut mucosal dendritic cell function. Eur J Immunol (2008) 38(6):1533-47. doi:10.1002/eji. 200737909

42. Fusi A, Liu Z, Kummerlen V, Nonnemacher A, Jeske J, Keilholz U. Expression of chemokine receptors on circulating tumor cells in patients with solid tumors. J Transl Med (2012) 10:52. doi:10.1186/1479-5876-10-52

43. Huber-Lang M, Sarma VJ, Lu KT, McGuire SR, Padgaonkar VA, Guo RF, et al. Role of C5a in multiorgan failure during sepsis. J Immunol (2001) 166(2):1193-9. doi:10.4049/jimmunol.166.2.1193

44. Paschos KA, Canovas D, Bird NC. The role of cell adhesion molecules in the progression of colorectal cancer and the development of liver metastasis. Cell Signal (2009) 21(5):665-74. doi:10.1016/j.cellsig.2009.01.006

45. Laubli H, Borsig L. Selectins promote tumor metastasis. Semin Cancer Biol (2010) 20(3):169-77. doi:10.1016/j.semcancer.2010.04.005

46. Alberda WJ, Dassen HP, Dwarkasing RS, Willemssen FE, van der Pool AE, de Wilt JH, et al. Prediction of tumor stage and lymph node involvement with dynamic contrast-enhanced MRI after chemoradiotherapy for locally advanced rectal cancer. Int J Colorectal Dis (2013) 28(4):573-80. doi:10.1007/s00384-0121576-6

47. Taichman RS, Cooper C, Keller ET, Pienta KJ, Taichman NS, McCauley LK. Use of the stromal cell-derived factor-1/CXCR4 pathway in prostate cancer metastasis to bone. Cancer Res (2002) 62(6):1832-7.

48. Jain S, Sharma P, Mukherjee A, Bal C, Kumar R. "Witch's milk" and $99 \mathrm{mTc}$-pertechnetate uptake in neonatal breast tissue: an uncommon but not unexpected finding. Clin Nucl Med (2013) 38(7):586-7. doi:10.1097/RLU. 0b013e318292aaba

49. Murakami T, Kawada K, Iwamoto M, Akagami M, Hida K, Nakanishi Y, et al. The role of CXCR3 and CXCR4 in colorectal cancer metastasis. Int J Cancer (2013) 132(2):276-87. doi:10.1002/ijc. 27670

50. Kawada K, Hosogi H, Sonoshita M, Sakashita H, Manabe T, Shimahara Y, et al. Chemokine receptor CXCR3 promotes colon cancer metastasis to lymph nodes. Oncogene (2007) 26(32):4679-88. doi:10.1038/sj.onc.1210267

51. Kim J, Takeuchi H, Lam ST, Turner RR, Wang HJ, Kuo C, et al. Chemokine receptor CXCR4 expression in colorectal cancer patients increases the risk for recurrence and for poor survival. J Clin Oncol (2005) 23(12):2744-53. doi:10.1200/JCO.2005.07.078

52. Ghadjar P, Coupland SE, Na IK, Noutsias M, Letsch A, Stroux A, et al. Chemokine receptor CCR6 expression level and liver metastases in colorectal cancer. J Clin Oncol (2006) 24(12):1910-6. doi:10.1200/JCO.2005.04.1822

53. Rubie C, Oliveira V, Kempf K, Wagner M, Tilton B, Rau B, et al. Involvement of chemokine receptor CCR6 in colorectal cancer metastasis. Tumour Biol (2006) 27(3):166-74. doi:10.1159/000092777

54. Rubie C, Oliveira-Frick V, Rau B, Schilling M, Wagner M. Chemokine receptor CCR6 expression in colorectal liver metastasis. J Clin Oncol (2006) 24(32):5173-4; author reply 4. doi:10.1200/JCO.2006.07.9095

55. Rubie C, Kollmar O, Frick VO, Wagner M, Brittner B, Graber S, et al. Differential CXC receptor expression in colorectal carcinomas. Scand J Immunol (2008) 68(6):635-44. doi:10.1111/j.1365-3083.2008.02163.x

56. Iwasa S, Yanagawa T, Fan J, Katoh R. Expression of CXCR4 and its ligand SDF-1 in intestinal-type gastric cancer is associated with lymph node and liver metastasis. Anticancer Res (2009) 29(11):4751-8.

57. Matsusue R, Kubo H, Hisamori S, Okoshi K, Takagi H, Hida K, et al. Hepatic stellate cells promote liver metastasis of colon cancer cells by the action of SDF1/CXCR4 axis. Ann Surg Oncol (2009) 16(9):2645-53. doi:10.1245/s10434-0090599-X 
58. Ghadjar P, Rubie C, Aebersold DM, Keilholz U. The chemokine CCL20 and its receptor CCR6 in human malignancy with focus on colorectal cancer. Int J Cancer (2009) 125(4):741-5. doi:10.1002/ijc.24468

59. Cambien B, Karimdjee BF, Richard-Fiardo P, Bziouech H, Barthel R, Millet MA, et al. Organ-specific inhibition of metastatic colon carcinoma by CXCR3 antagonism. Br J Cancer (2009) 100(11):1755-64. doi:10.1038/sj.bjc.6605078

60. Guillemot E, Karimdjee-Soilihi B, Pradelli E, Benchetrit M, Goguet-Surmenian E, Millet MA, et al. CXCR7 receptors facilitate the progression of colon carcinoma within lung not within liver. Br J Cancer (2012) 107(12):1944-9. doi:10.1038/bjc.2012.503

61. Strell C, Entschladen F. Extravasation of leukocytes in comparison to tumor cells. Cell Commun Signal (2008) 6:10. doi:10.1186/1478-811X-6-10

62. Vega MT, Martin AD. The significance of toll-like receptors in human diseases. Allergol Immunopathol (Madr) (2009) 37(5):252-63. doi:10.1016/j.aller.2009.04. 004

63. Harmey JH, Bucana CD, Lu W, Byrne AM, McDonnell S, Lynch C, et al. Lipopolysaccharide-induced metastatic growth is associated with increased angiogenesis, vascular permeability and tumor cell invasion. Int J Cancer (2002) 101(5):415-22. doi:10.1002/ijc.10632

64. Koretz K, Schlag P, Boumsell L, Moller P. Expression of VLA-alpha 2, VLA-alpha 6, and VLA-beta 1 chains in normal mucosa and adenomas of the colon, and in colon carcinomas and their liver metastases. Am J Pathol (1991) 138(3):741-50.

65. Liapis H, Flath A, Kitazawa S. Integrin alpha V beta 3 expression by boneresiding breast cancer metastases. Diagn Mol Pathol (1996) 5(2):127-35. doi:10. 1097/00019606-199606000-00008

66. Seftor RE, Seftor EA, Gehlsen KR, Stetler-Stevenson WG, Brown PD, Ruoslahti E, et al. Role of the alpha v beta 3 integrin in human melanoma cell invasion. Proc Natl Acad Sci U S A (1992) 89(5):1557-61. doi:10.1073/pnas.89.5.1557

67. Man YG, Stojadinovic A, Mason J, Avital I, Bilchik A, Bruecher B, et al. Tumorinfiltrating immune cells promoting tumor invasion and metastasis: existing theories. J Cancer (2013) 4(1):84-95. doi:10.7150/jca.5482

68. Holzel M, Bovier A, Tuting T. Plasticity of tumour and immune cells: a source of heterogeneity and a cause for therapy resistance? Nat Rev Cancer (2013) 13(5):365-76. doi: $10.1038 / \mathrm{nrc} 3498$

69. Seyfried TN, Huysentruyt LC. On the origin of cancer metastasis. Crit Rev Oncog (2013) 18(1-2):43-73. doi:10.1615/CritRevOncog.v18.i1-2.40

70. Tarin D. Inappropriate gene expression in human cancer and its far-reaching biological and clinical significance. Cancer Metastasis Rev (2012) 31(1-2):21-39. doi:10.1007/s10555-011-9326-8

71. Seftor RE, Hess AR, Seftor EA, Kirschmann DA, Hardy KM, Margaryan NV, et al. Tumor cell vasculogenic mimicry: from controversy to therapeutic promise. Am J Pathol (2012) 181(4):1115-25. doi:10.1016/j.ajpath.2012.07.013

72. Tarin D, Thompson EW, Newgreen DF. The fallacy of epithelial mesenchymal transition in neoplasia. Cancer Res (2005) 65(14):5996-6000; discussion 6000-1. doi:10.1158/0008-5472.CAN-05-0699

73. Wirtz D, Konstantopoulos K, Searson PC. The physics of cancer: the role of physical interactions and mechanical forces in metastasis. Nat Rev Cancer (2011) 11(7):512-22. doi:10.1038/nrc3080

74. Schramm HM. Should EMT of cancer cells be understood as epithelial-myeloid transition? J Cancer (2014) 5(2):125-32. doi:10.7150/jca.8242

75. Pawelek JM. Tumour-cell fusion as a source of myeloid traits in cancer. Lancet Oncol (2005) 6(12):988-93. doi:10.1016/S1470-2045(05)70466-6

76. Pawelek JM, Chakraborty AK. The cancer cell-leukocyte fusion theory of metastasis. Adv Cancer Res (2008) 101:397-444. doi:10.1016/S0065-230X(08)00410-7

77. Masopust D, Schenkel JM. The integration of T cell migration, differentiation and function. Nat Rev Immunol (2013) 13(5):309-20. doi:10.1038/nri3442

78. Brinkman CC, Peske JD, Engelhard VH. Peripheral tissue homing receptor control of naive, effector, and memory CD8 T cell localization in lymphoid and nonlymphoid tissues. Front Immunol (2013) 4:241. doi:10.3389/fimmu.2013.00241

79. Tufail S, Badrealam KF, Sherwani A, Gupta UD, Owais M. Tissue specific heterogeneity in effector immune cell response. Front Immunol (2013) 4:254. doi:10.3389/fimmu.2013.00254

80. Erreni M, Bianchi P, Laghi L, Mirolo M, Fabbri M, Locati M, et al. Expression of chemokines and chemokine receptors in human colon cancer. Methods Enzymol (2009) 460:105-21. doi:10.1016/S0076-6879(09)05205-7

81. Hwang TL, Lee LY, Wang CC, Liang Y, Huang SF, Wu CM. CCL7 and CCL21 overexpression in gastric cancer is associated with lymph node metastasis and poor prognosis. World J Gastroenterol (2012) 18(11):1249-56. doi:10.3748/wjg.v18. i11.1249

82. Kitayama J, Nagawa H, Tsuno N, Osada T, Hatano K, Sunami E, et al. Laminin mediates tethering and spreading of colon cancer cells in physiological shear flow. Br J Cancer (1999) 80(12):1927-34. doi:10.1038/sj.bjc.6690622

83. Roy J, Audette M, Tremblay MJ. Intercellular adhesion molecule-1 (ICAM-1) gene expression in human $\mathrm{T}$ cells is regulated by phosphotyrosyl phosphatase activity. Involvement of NF-kappaB, Ets, and palindromic interferon-gammaresponsive element-binding sites. J Biol Chem (2001) 276(18):14553-61. doi:10. 1074/jbc.M005067200

84. Ding YB, Chen GY, Xia JG, Zang XW, Yang HY, Yang L. Association of VCAM-1 overexpression with oncogenesis, tumor angiogenesis and metastasis of gastric carcinoma. World J Gastroenterol (2003) 9(7):1409-14.

85. Burdick MM, Chu JT, Godar S, Sackstein R. HCELL is the major E- and Lselectin ligand expressed on LS174T colon carcinoma cells. J Biol Chem (2006) 281(20):13899-905. doi:10.1074/jbc.M513617200

86. Zetter BR. Adhesion molecules in tumor metastasis. Semin Cancer Biol (1993) 4(4):219-29.

87. Caruso RA, Fedele F, Finocchiaro G, Arena G, Venuti A. Neutrophil-tumor cell phagocytosis (cannibalism) in human tumors: an update and literature review. Exp Oncol (2012) 34(3):306-11.

88. Song J, Sapi E, Brown W, Nilsen J, Tartaro K, Kacinski BM, et al. Roles of Fas and Fas ligand during mammary gland remodeling. J Clin Invest (2000) 106(10):1209-20. doi:10.1172/JCI10411

89. Mullauer L, Mosberger I, Grusch M, Rudas M, Chott A. Fas ligand is expressed in normal breast epithelial cells and is frequently up-regulated in breast cancer. J Pathol (2000) 190(1):20-30. doi:10.1002/(SICI)1096-9896(200001)190:1<20: :AID-PATH497>3.0.CO;2-S

90. Spriggs DR, Imamura K, Rodriguez C, Sariban E, Kufe DW. Tumor necrosis factor expression in human epithelial tumor cell lines. J Clin Invest (1988) 81(2):455-60. doi:10.1172/JCI113341

91. Humbert L, Lebrun JJ. TGF-beta inhibits human cutaneous melanoma cell migration and invasion through regulation of the plasminogen activator system. Cell Signal (2013) 25(2):490-500. doi:10.1016/j.cellsig.2012.10.011

92. Shi F, Shi M, Zeng Z, Qi RZ, Liu ZW, Zhang JY, et al. PD-1 and PDL1 upregulation promotes CD8(+) T-cell apoptosis and postoperative recurrence in hepatocellular carcinoma patients. Int J Cancer (2011) 128(4):887-96. doi:10.1002/ijc. 25397

93. Shi SJ, Wang LJ, Wang GD, Guo ZY, Wei M, Meng YL, et al. B7-H1 expression is associated with poor prognosis in colorectal carcinoma and regulates the proliferation and invasion of HCT116 colorectal cancer cells. PLoS One (2013) 8(10):e76012. doi:10.1371/journal.pone.0076012

94. Koscielny S, Le MG, Tubiana M. The natural history of human breast cancer. The relationship between involvement of axillary lymph nodes and the initiation of distant metastases. Br J Cancer (1989) 59(5):775-82. doi:10.1038/bjc. 1989.162

95. Jatoi I, Hilsenbeck SG, Clark GM, Osborne CK. Significance of axillary lymph node metastasis in primary breast cancer. J Clin Oncol (1999) 17(8): 2334-40.

Conflict of Interest Statement: The authors declare that the research was conducted in the absence of any commercial or financial relationships that could be construed as a potential conflict of interest.

Received: 22 April 2014; accepted: 22 August 2014; published online: 20 October 2014. Citation: Luddy KA, Robertson-Tessi M, Tafreshi NK, Soliman H and Morse DL (2014) The role of toll-like receptors in colorectal cancer progression: evidence for epithelial to leucocytic transition. Front. Immunol. 5:429. doi: 10.3389/fimmu.2014.00429

This article was submitted to Tumor Immunity, a section of the journal Frontiers in Immunology.

Copyright (C) 2014 Luddy, Robertson-Tessi, Tafreshi, Soliman and Morse. This is an open-access article distributed under the terms of the Creative Commons Attribution License (CC BY). The use, distribution or reproduction in other forums is permitted, provided the original author(s) or licensor are credited and that the original publication in this journal is cited, in accordance with accepted academic practice. No use, distribution or reproduction is permitted which does not comply with these terms. 